\title{
Application of S. cerevisiae isolated from industrial effluent for zinc biosorption and zinc-enriched SCP production
}

\author{
Forough Saraei ${ }^{1}$, Kurmass Amini $^{2}$, Azam Haddadi $^{1}$, and mohaddeseh Larypoor ${ }^{3}$ \\ ${ }^{1}$ Karaj Islamic Azad University \\ ${ }^{2}$ Islamic Azad University Saveh Branch \\ ${ }^{3}$ Islamic Azad University Tehran North Branch
}

June 25, 2020

\begin{abstract}
Purpose: The aim of present study was to produce high quantity of Zn-enriched yeast biomass in the presence of zinc metal, using S. cerevisiae as an industrially important yeast strain. Methods: Yeast isolates were obtained from two alcohol factories and S. cerevisiae yeasts strains were identified using PCR method and DNA sequencing. Then, growth rate of this yeast in present of $\mathrm{Zn} 2+$ as well as the level of $\mathrm{Zn} 2+$ uptake by the yeast cells, were examined at 24-hour intervals $(0,24,48$, and $72 \mathrm{~h})$, using spectrophotometry and AAS method. qRT-PCR technique was carried out to quantified expression level of Zrt1 and Fet4 in yeast cells under these conditions. Also, the effect of $\mathrm{pH}$ of culture medium on yeast growth rate, zinc absorbtion and Zrt1 and Fet4 expression level, was studied. After setting the optimum pH, Kjeldahl's method was applied for assessment of total protein content of yeast cells. Results: In optimum conditions of $25 \mu \mathrm{g} / \mathrm{ml}$ of zinc in $\mathrm{pH} 6$ and $24 \mathrm{~h}$ incubation, S. cerevisiae showed the maximum growth rate, zinc uptake and expression level of Zrt1 and Fet4 as Zn transporters. Also, protein content of S. cerevisiae biomass in these optimum conditions was above $50 \%(\mathrm{w} / \mathrm{w})$. Discussion: we demonstrated that industrial effluents can be used to produce Zn-enriched biomass however, further researches are required.
\end{abstract}

\section{Introduction}

The rapidly growing industrialization of the world has an impact on the quality of water, food, feed, and weather as results of high amounts of toxic substances released by various industries to the environment $(1,2)$. Also, pesticides and chemical composts in agriculture as well as vehicles for transportation cause to separate large quantities of pollutants in atmosphere (3); The heavy metals as a main kind of these pollutants considerably threaten the food safety because of their accumulation in water and food (4-9), and consequently, affecting human organs and tissues (1-3).

Heavy metals are classified into three categories including: toxic metals, precious metals and radionuclides. One of the toxic metals, with a significant role in water pollution is zinc $(6,10,11)$. This essential element is used in many growing economic sectors, and thereby, large quantities of this heavy metal discharge into the industrial effluents (12-15). Zinc as an essential element, has many important biological impact such as: being as a major ion in structure of motifs, act as a catalytic factor of enzymes (16), essential role in the structure and function of nucleic acid and protein along with accompanying in gene expression and immune system development $(17,18)$. So, deficiency of zinc contributes to the impaired function of innate immune response such as phagocytosis, cytokine secretion, neutrophils and natural killer cells functions. Also, zinc deficiency impacts on impaired antibody secretion, thymic atrophy and lymphopenia (19).

Microorganisms, like humans, are dependent on appropriate levels of zinc for their vital reactions. For example; in yeast about $8 \%$ of the proteome is thought to bind zinc $(19,20)$ and about 400 genes involved in growth are zinc-dependent $(20,21)$. Several investigations have been conducted mainly, in Saccharomyces 
cerevisiae, as a yeast, suggesting the requirement of zinc homeostasis in growth and metabolism (20). There are two main classes of eukaryotic zinc transporters in S. cerevisiae. The Zrt1, Zrt2 and Zrt3 are classified in ZIP proteins (ZRT-IRT-like protein) (19, 22, as well as, Zrc1, Cot1, Msc2 and Zrg17 that classified in cation diffusion facilitator $(23,24)$. In the case of severe zinc limitation, extracellular uptake of zinc in $S$. cerevisiae mediated by the high-affinity Zrt1 protein which contributes to increasing of the ZRT1 expression up to 30-fold. Moreover, this microorganism can partially adopt with conditions of low zinc by expression of Fet4, a low-affinity metal transporter, to import zinc, iron, and copper into the cell (19).

Biosorption strategies have been considered for many years to solve the problem of heavy metal pollution and consequently environmental remediation. Among all living organisms, applied to absorb toxic elements, microorganisms have attracted increasing attention, because they have safety in human aspects and are easier to work with (25-27). Despite its mediocre capacity, the $S$. cerevisiae is a unique biomaterial in heavy metals biosorption (28) and due to easy cultivation in a large scale and manipulation at the molecular level as well as high biomass production, makes the $S$. cerevisiae to be administered in biomaterial approaches (11). Based on these considerations, our investigation was conducted for study of yeasts with emphasis on $S$. cerevisiae as an industrially important strain, isolated from industrial effluents, for biosorption of zinc and the applied the produced biomass as zinc-enriched single cell protein (SCP) in feed and food production.

\section{Materials and Methods}

\section{Sample collection, isolation and preparation}

Fresh effluent samples obtained from two alcohol factories in Iran, were collected in sterile glass containers, closed tightly and transferred to the laboratory for further analysis. Filtration of effluent samples was performed using $0.45 \mu \mathrm{m}$ pore size filter paper. Then, filter papers containing microorganisms of effluent were grown in YPD (yeast extract-peptone-dextrose) medium that is a specific medium for yeast growth. The temperature was controlled at $28^{\circ} \mathrm{C}$ with shaking at $150 \mathrm{rpm}$ until OD reached $0.5\left(\sim 1.5 \times 10^{7} \mathrm{cell} / \mathrm{ml}\right)$ at $600 \mathrm{~nm}$, representing the middle of the logarithmic (mid-log) phase. Grown yeasts were harvested in the mid-log phase by centrifugation at $3000 \times \mathrm{g}$ for $10 \mathrm{~min}$ and after washing the yeast pellets with distilled water for three times, it is stored at $-20{ }^{\circ} \mathrm{C}$.

\section{Examination of Zrt1 and Fet4 genes in isolated yeasts and identification of yeast's strain}

The total DNA was extracted from cells which were directly collected from yeast pellets, with DNA extraction kit (CinnaGen, Iran) according to manufacturer's protocol. The concentrations of all DNA samples were quantified with NanoDropTM and DNAs were used in the subsequent PCR procedures:

Examination of Zrt1 and Fet4 genes. To isolation of samples which express Zrt1 and Fet4 genes, PCR reaction was performed using primers of F: 5' AAATGCACTAGAACATGGCG 3' and R: 5' TTCATGACTATTTAAATGCCTT 3' for Zrt1 gene as well as F: 5' GGAGAACTGCCTGTGGAAAA 3' and R: 5' GAGGGCCATGAAGGTATCAA 3' for Fet4 gene, under following program: 95degC (3 min), 95degC (30 sec), 59degC (30 sec, 35 cycles), $72 \mathrm{deg} \mathrm{C}(1 \mathrm{~min})$, and final extension step at $72 \mathrm{deg} \mathrm{C}(10 \mathrm{~min})$. Then PCR products were electrophoresed and results were observed on $1.5 \%$ agarose gel.

Identification of yeast's strain. After isolating samples which express Zrt1 and Fet4 genes, the identification of yeast strain was performed using a common PCR methods. ITS1: 5' TCCGTAGGTGAACCTTGCGG 3' and ITS4: 5' TCCTCCGCTTATTGATATGC 3'primers were used in PCR reaction with following program: $94 \operatorname{deg} \mathrm{C}(1 \mathrm{~min}, 35$ cycles$), 55.5 \operatorname{deg} \mathrm{C}(2 \mathrm{~min}), 72 \operatorname{deg} \mathrm{C}(2 \mathrm{~min})$, and final extension step at $72 \operatorname{deg} \mathrm{C}(10$ min). Then PCR products were electrophoresed and results were observed on $1.5 \%$ agarose gel. The samples which showed the related fragments were verified by sequencing (Bioneer Co, Korea).

\section{Estimation of growth rate and assessment of absorbed zinc inS. cerevisiae}

The effect of $\mathrm{Zn}{ }^{2+}$ concentration on efficiency of zinc biosorption as well as biomass production in actively growing S. cerevisiae, was evaluated. The $\mathrm{ZnSO}_{4}$ solution, prepared using a $1000 \mathrm{mg} / \mathrm{l}$ sterile stock solution of zinc sulfate heptahydrate (Merck, Germany), was diluted to various concentrations of zinc including 0 , 
10, 25, 50 and $100 \mathrm{mg} / \mathrm{l}$; every concentration was added in a $500 \mathrm{ml}$ Erlenmeyer flask containing $200 \mathrm{ml}$ SDB (sabouraud dextrose broth) culture medium. Then S. cerevisiae pellets (containing $\sim 1.5 \times 10^{7}$ cell/ml) were inoculated to these zinc supplemented mediums. The content of all flasks (control and experimental cultures) were incubated in $28 \mathrm{degC}$ in the shaker incubator at agitation speed of $200 \mathrm{rpm} / \mathrm{min}$ for $72 \mathrm{~h}$, with the pH adjusted at 5.8. Then, growth rate of $S$. cerevisiae in present of $\mathrm{Zn}^{2+}$ as well as the level of $\mathrm{Zn}{ }^{2+}$ absorption by $S$. cerevisiae were considered as follows:

Growth rate estimation. During cultivation of yeast in the presence of zinc, the yeast growth at 24-hour intervals $(0,24,48$, and $72 \mathrm{~h}$ ) was estimated; the optical density (OD) of suspension was determined using spectroscopic method at $600 \mathrm{~nm}$ wavelength. Also, $10 \mathrm{ml}$ of medium was collected and centrifuged at 4000 $\mathrm{rpm}$ in $20 \mathrm{deg} \mathrm{C}$ for $10 \mathrm{~min}$, then immediately supernatant was removed and the weight of sediment was assayed. After that, to determine the content of dry biomass, a two-stage drying procedure including: first temperature at $60 \operatorname{deg} \mathrm{C}$ for $2 \mathrm{~h}$ and second stage at $105 \mathrm{degC}$ was performed to obtain the constant weight and then, dried biomass was weighed and considered as cell dry weight (CDW).

AAS determination. To determine the total accumulation of zinc in yeast cells at 24-hour intervals, Atomic Absorption Spectrophotometry (AAS) method was performed. In brief, $1 \mathrm{mg}$ dry biomass was digested by adding nitric acid and distilled water (1:1) in $25 \mathrm{ml}$ digestion tubes for $20 \mathrm{~min}$ at $160 \mathrm{degC}$, then the obtained biomass was filtered via filter paper. Finally AAS method was applied to estimate the content of zinc in yeast cell biomass at $213.9 \mathrm{~nm}$ wavelength.

Determination of dry content of biomass and AAS for each samples were repeated three times.

Determination of $\mathrm{Zn}^{2+}$ concentrations on $\mathrm{Zrt1}$ and Fet4 expression level in $S$. cerevisiae

EZ-10 Spin Column Fungal RNA Miniprep Kit (Bio Basic, Canada) was applied according to the manufacturer's structure, to isolate total RNA from zinc absorbed yeasts. Then, cDNA was immediately prepared with the AccuPower RocketScript RT PreMix (Bioneer, Korea). Subsequently, relative quantification of Zrt1 and Fet4 expression was determined using quantitative real time PCR (qRT-PCR) with RealQ Plus 2x Master Mix Green (Ampliqon Co, Denmark). The qRT-PCR reactions were prepared in a total volume of $20 \mu \mathrm{l}$ and cycling conditions of $95^{\circ} \mathrm{C}(15 \mathrm{~min})$, followed by $95^{\circ} \mathrm{C}(20 \mathrm{~s}, 40 \mathrm{cycles})$, and $60^{\circ} \mathrm{C}(1 \mathrm{~min})$ was performed. We used same designed primers of Zrt1 and Fet4 genes which had been used in yeasts isolation step; also F: 5' AAACGGCTACCACATCCAAG 3' and R: 5' CCCATCCCAAGGTTCAACTA 3' pairs were applied for amplification of $18 \mathrm{SrRNA}$ gene as internal control. Finally, melting curve analysis was considered to validate the specificity of the expected PCR product as well as nonoccurrence of primer-dimer formation. All reactions were carried out in triplicate and the results were analyzed by threshold cycle $(\mathrm{Ct})$ values.

Determination of optimum $\mathrm{pH}$ for maximum zinc absorbed group and examination of growth rate as well as Zrt1 and Fet4 expression level in this pH

After determination of absorbed zinc by yeast biomass in all zinc treated groups, a yeast biomass with maximum growth rate, absorbed zinc, and expression level of Zrt1 and Fet4 in yeast cells, were selected. This group was considered to study at $\mathrm{pH} 3,4,5$ and 6 , under conditions that mentioned in the previous section, to find the optimum $\mathrm{pH}$ for maximum zinc absorption. In the following, estimation of growth rate and total accumulation of zinc in yeast cells as well as determination of Zrt1 and Fet4 expression level in zinc absorbed yeasts were performed as mentioned earlier (spectrophotometry, CDW estimation, and qRT-PCR).

\section{Assessment of total protein content}

After adjusting the optimum $\mathrm{pH}$, the total protein content of yeast cells was assayed. For this purpose, Kjeldahl's method was carried out via conversion of total nitrogen content into total protein content by the coefficient factor 6.25 .

\section{Statistical analysis}

In the current study, all the measurements were performed three times and the obtained results were average of the three replications. SPSS software v.16 was used for statistical analysis and data were analyzed using 
ANOVA. The numerical data were presented as mean +- SD (standard deviations) and ${ }^{*} \mathrm{p}<0.05,{ }^{* *} \mathrm{p}<$ 0.01 , and ${ }^{* * *} \mathrm{p}<0.001$ were indicated as significant $\mathrm{p}$ values.

\section{Results}

\section{S. cerevisiae yeasts were obtained from alcohol factory's effluent}

A total of 52 microorganism samples from alcohol factory's effluent after preparation and cultivation of these samples on the complete medium for yeast growth, were isolated and their total DNA were extracted. Then the PCR method was performed to examine Zrt1 and Fet4 genes in these samples. Four samples expressing Zrt1 and Fet4 genes which illustrated fragment patterns of $2102 \mathrm{bp}$ and $165 \mathrm{bp}$ on $1.5 \%$ agarose gel in relation with Zrt1 and Fet4 genes, respectively, were identified (figure 1A). Subsequently, after isolation of samples which express Zrt1 and Fet4 genes, the yeast strains of these four samples were identified using PCR of ITS1 and ITS4 primers. Then PCR products were electrophoresed and results observed on 1.5\% agarose gel and three out of four samples illustrated fragment patterns in relation with ITS, representing these three samples as yeast strains (figure1B). Then related fragments were verified by sequencing and the results identified two samples as $S$. cerevisiae yeasts (figure 1C). All results of gel electrophoresis as well as phylogenetic tree of sequenced samples were illustrated in figure 1 (to observe the results of sample sequencing see the supplementary pdf file 1 ).

\section{Zinc concentrations effect on $\boldsymbol{S}$. cerevisiae growth rate and its zinc absorption}

The effect of zinc concentrations on the yield of yeast biomass and the biosorption of zinc by yeast cells of $S$. cerevisiae strain was evaluated. The effects of supplementing the SDB culture medium with $\mathrm{ZnSO}_{4}$ on the yeast growth rate were examined at 24-hour intervals $(0,24,48$, and $72 \mathrm{~h})$ and the results were assayed using spectroscopic methods. The highest growth rate at 24 hours after inoculation in the presence of $25 \mu \mathrm{g} / \mathrm{ml}$ of zinc concentration $\left(\mathrm{OD}_{600}=2.520 \mu \mathrm{g} / \mathrm{ml}\right)$, was observed. Actually, the growth rate of $S$. cerevisiae in culture medium gradually increased correspondingly with the incubation time $(0-24 \mathrm{~h})$ and $25 \mu \mathrm{g} / \mathrm{ml}$ of zinc concentration and leveled off at $24 \mathrm{~h}$ after inoculation (figure 2). Dry matter content of yeast biomass also illustrated the maximum weight $24 \mathrm{~h}$ after inoculation in the presence of $25 \mu \mathrm{g} / \mathrm{ml}$ of zinc concentration ( $0.206 \mathrm{~g}$ of dry yeast biomass $/ 200 \mathrm{ml}$ SDB medium), verifying the optical density result of this group. Also, the maximum uptake of zinc by yeast cells was observed using AAS method at $24 \mathrm{~h}$ after inoculation; suggesting that, the increment of incubation time after $24 \mathrm{~h}$, did not positively affect biosorption (table 1).

Table 1. Effect of zinc concentrations on the yield of dry yeast biomass and zinc uptake by S. cerevisiae

\begin{tabular}{ll}
\hline Different concentrations of $\mathrm{ZnSO}_{4}$ in SDB culture medium & Different concentrations of $\mathrm{ZnSO}_{4}$ in SDB culture medium \\
\hline 100 & 100 \\
RSD & $\mathrm{Zn}^{2+}$ uptake \\
0.4 & 51.02 \\
0.8 & 40.39 \\
0.3 & 33.78 \\
& Time: incubation time after inoculation (h), CDW: cell dry \\
\hline
\end{tabular}

\section{Zinc concentrations change Zrt1 and Fet4 expression level inS. cerevisiae}

The significant growth rate changes as well as maximum uptake of zinc by yeast cells at $24 \mathrm{~h}$ after inoculation was observed. Therefore, the qRT-PCR technique was applied to determine Zrt1 and Fet4 expression level in $S$. cerevisiae at 24 hours after inoculation. The results showed that under supplementing the SDB medium with different concentrations of zinc, the expression of Zrt1 and Fet4 changed noticeably. The Zrt1 expression reached a maximum level already after $24 \mathrm{~h}$ of incubation in $25 \mu \mathrm{g} / \mathrm{ml}$ of zinc concentration; also increment of Fet4 expression in present of $25 \mu \mathrm{g} / \mathrm{ml}$ of zinc was considerable. While the maximum level of Fet4 expression was observed in $50 \mu \mathrm{g} / \mathrm{ml}$ of zinc concentration. Hence, this relative quantification of Zrt1 
and Fet4 expression verified the $24 \mathrm{~h}$ incubation and $25 \mu \mathrm{g} / \mathrm{ml}$ of zinc concentration as optimum time and zinc concentration, respectively for $S$. cerevisiae yeast (figure 3 ).

\section{Optimum pH 6 was identified for maximum yield of yeast biomass and Zrt1 and Fet4 expression level}

Based on 24-hour intervals, the group in which maximum growth rate, absorbed zinc, and expression level of Zrt1 and Fet4 in yeast cells had been observed (the group under conditions of $24 \mathrm{~h}$ incubation and $25 \mu \mathrm{g} / \mathrm{ml}$ of zinc concentration), was selected; then to identify the optimum $\mathrm{pH}$ for this group, proper for maximum zinc absorption, cultivation and zinc treatment was repeated at $\mathrm{pH} 3,4,5$ and 6 . The maximum growth rate as well as total accumulation of zinc in yeast cells was observed at $\mathrm{pH} 6$; suggesting the optimum $\mathrm{pH}$ for $24 \mathrm{~h}$ incubation and $25 \mu \mathrm{g} / \mathrm{ml}$ of zinc concentration for maximum yield of yeast biomass (table 2). Also, the expression level of Zrt1 and Fet4 in zinc absorbed yeasts in these different $\mathrm{pH}$ values (pH 3-6) was evaluated. The maximum level of Fet4 expression was observed in $\mathrm{pH}$ 4, while the equal increment of Zrt1 and Fet4 expression was observed in $\mathrm{pH} 6$ (figure 4).

Table 2. Effect of $\mathrm{pH}$ on yield of yeast biomass

\begin{tabular}{ll}
\hline $\mathrm{pH}$ & 3 \\
\hline $\mathrm{OD}$ & 1.780 \\
$\mathrm{CDW}$ & 0.10 \\
$\mathrm{pH} 5.8:$ primary $\mathrm{pH}$ of SDB medium, OD: optical density $(\mu \mathrm{g} / \mathrm{ml}), \mathrm{CDW}:$ cell dry weight $(\mathrm{g} / 200 \mathrm{ml}$ SDB$)$ & $\mathrm{pH} 5.8:$ prim \\
\hline
\end{tabular}

\section{S. cerevisiae has ability to produce high amount of protein content}

The total protein content of yeast cells was assayed, after adjusting the optimum $\mathrm{pH}$. The protein content of the sample under conditions of $24 \mathrm{~h}$ incubation and $25 \mu \mathrm{g} / \mathrm{ml}$ of zinc concentration at optimum $\mathrm{pH} 6$, based on the Kjeldahl method, was $61.4 \mathrm{~g} / \mathrm{L}$. This estimation was conducted by multiplying total nitrogen by the coefficient factor of 6.25 and the result showed that protein content of the yeast biomass was above $50 \%(\mathrm{w} / \mathrm{w})$.

\section{Discussion}

The world's population is expected to reach more than 9 billion people by 2050 (29); consequently, there will be concerns about the nutritional adequacy, especially for animal-derived protein, of such a population (30). These concerns force mankind to attempt finding alternative protein sources to replace or supplement plant proteins (29). Since, plant-based proteins require the use of arable land (31) and fish meals are based on catch of wild fish stocks (29), other sources of protein with high nutritional value need to be identified and developed.

Single cell proteins (SCP), produced by bacteria, algae or fungi, are one of microbial proteins which have been considered by researchers as suitable sources of nutritional protein (29); due to highly nutritious, cheap, and rapidly synthesized properties (32). Among SCP producing microorganisms, yeasts are preferred candidates because of their proper characteristics; the yeasts have rapid growth and high protein content as well as low risk of contamination. Also their cell size and flocculation abilities makes them easy to harvest (29). Yeasts are capable of providing vitamins and a well-balanced source of amino acids (33), whereas, contain lower amounts of nucleic acids in comparison with bacteria; that is an advanced property for human food and animal feed ingredients $(29,32)$. Yeasts are able to convert low-cost and readily available industrial organic by-products to high quality protein and lipids, efficient for animal feed as well as for human consumption. Furthermore, because of yeast's ability to bind metal ions from the culture medium, they may be applied as a source of protein production and mineral preparations that can be easily utilized by humans (29). 
In order to produce yeast biomass as a source of SCP, identification of yeast strains with optimal properties is of tremendous value. The Saccharomyces cerevisiae is a promising biosorbent yeast which is considered as a model system to accumulate metals in fairly high concentrations; and due to this ability, it is widely employed in many branches of industry $(34,35)$. The uptake and accumulation of zinc, as a required element for catalytic, regulatory and structural role in many proteins (36), by $S$. cerevisiae has been proven (18). Considering this, our present study focused on S. cerevisiae as well-studied yeast, obtained from alcohol factory's effluent (figure 1), to produce zinc-enriched SCP under optimal conditions.

Numerous parameters could affect the absorption of zinc by yeast cells including: cell physiology, cell surface properties as well as chemistry of the metal ions and physicochemical impacts of the environment (18). In current study, we used different concentrations of zinc metal in SDB culture medium to find optimum zinc concentration to obtain a high yield of yeast biomass and zinc biosorption; simultaneously, the effect of incubation time on yeast growth was also investigated. Using the AAS method, the maximum uptake of zinc by yeast cells was observed at $24 \mathrm{~h}$ after inoculation; suggesting that, the increment of incubation time more than $24 \mathrm{~h}$, did not positively affect biosorption (table 1). The maximum dry matter content as well as highest growth rate of yeast biomass were observed in $25 \mu \mathrm{g} / \mathrm{ml}$ of zinc in SDB medium and after 24 $\mathrm{h}$ incubation (figure 2 and table1); suggesting $25 \mu \mathrm{g} / \mathrm{ml}$ as optimal concentration of zinc for $S$. cerevisiae growth.

The strong changes in expression level of Zrt1 and Fet4, as zinc transporters, in response to zinc concentrations and $24 \mathrm{~h}$ incubation of $S$. cerevisiae in SDB medium, versus control medium (SDB without the addition of zinc) was observed, indicating the validity of obtained results. The Zrt1 expression reached a maximum level of $25 \mu \mathrm{g} / \mathrm{ml}$ of zinc concentration; also increment of Fet4 expression in present of $25 \mu \mathrm{g} / \mathrm{ml}$ of zinc was considerable. While the maximum level of Fet4 expression was observed in the presence of $50 \mu \mathrm{g} / \mathrm{ml}$ of zinc (figure 3). Hence, our observation was in accordance with previous study that mentioned uptake of extracellular zinc in S. cerevisiae, in severe zinc limitation, using the high-affinity zinc transporter, Zrt1; whereas, this yeast can partially cope with low zinc conditions by Fet4 as a low-affinity transporter protein for zinc, iron, and copper (19). Therefore, relative quantification of Zrt1 and Fet4 expression in our study, verified at $24 \mathrm{~h}$ incubation with $25 \mu \mathrm{g} / \mathrm{ml}$ of zinc concentration, as optimum time and zinc concentration for S. cerevisiae yeast, respectively (figure 3 ).

Due to the pH-dependency of zinc uptake, optimum $\mathrm{pH}$ for zinc biosorption by yeast cell is very important (37); in a study conducted by Chen and Wang in 2007, $\mathrm{pH} 5.8$ was identified as optimum pH for zinc biosorption by $S$. cerevisiae (35). On the basis of this report we used the same $\mathrm{pH}$ for yeast cultivation. After identifying the optimal conditions ( $25 \mu \mathrm{g} / \mathrm{ml}$ of zinc and $24 \mathrm{~h}$ incubation) for $S$. cerevisiae, an optimum $\mathrm{pH}$ of the medium as a critical parameter for zinc uptake by yeast cell was evaluated. By screening of growth rate, zinc uptake and expression level of Zrt1 and Fet4 in S. cerevisiae in different $\mathrm{pH}$ values (pH 3-6) under optimal conditions ( $25 \mu \mathrm{g} / \mathrm{ml}$ of zinc and $24 \mathrm{~h}$ incubation) an optimum $\mathrm{pH}$ was obtained. By increasing the $\mathrm{pH}$ of the medium from 3 to 6 , cellular zinc occurrence and yeast growth rate significantly increased and the highest increment were obtained in $\mathrm{pH} 6$, almost similar to results in $\mathrm{pH} 5.8$ (table 2). The maximum Fet4 transcript level was observed in $\mathrm{pH}$ 4, while the equal increment of Zrt1 and Fet4 expression was observed in $\mathrm{pH} 6$ (figure 4). As a result, our study approved the previous report of direct dependence of biosorption efficiency to $\mathrm{pH}$ of medium (38-40).

The crude protein content of the yeast cells could be affected by the strain, growth culture medium and growth conditions. So, the total protein content of yeast cells, under optimal conditions of $25 \mu \mathrm{g} / \mathrm{ml}$ of zinc at $\mathrm{pH} 6$ after $24 \mathrm{~h}$ incubation was evaluated. The results of this estimation showed that protein content of $S$. cerevisiae biomass was above $50 \%$ (w/w). The value obtained in our study was within protein levels, considered reasonable in the context of SCP production. Our results also augment other studies about the protein contents in yeasts which normally vary between 45 and $55 \%(29-31,41)$.

\section{Conclusions}

Present study was aimed to produce a high quantity of zinc-enriched yeast biomass in the presence of zinc 
metal using $S$. cerevisiaeas an industrially important yeast strain. The optimum zinc concentration in the culture medium and its effect on the yeast growth rate and zinc content in yeast biomass was determined. Our investigation appeared that $S$. cerevisiae biomass and protein production value under optimal conditions was similar to other studies. Importantly,S. cerevisiae is a promising candidate for SCP production because it has beneficial functional properties; such as high potential for biotechnological and especially food-related applications as well as ability to produce high amounts of protein content (around $50 \mathrm{w} / \mathrm{w} \%$ ). In summary, our study demonstrated the possibility of upgrading low value industrial effluents to SCP that can be used as a high-quality feed ingredient. Nevertheless, further research is required to develop an economically SCP process and introduce feed ingredients based on industrial side streams as substrates.

\section{References}

1. Owolabi J, Hekeu M. Heavy metal resistance and antibiotic susceptibility pattern of bacteria isolated from selected polluted soils in Lagos and Ota, Nigeria. International Journal of Basic \& Applied Sciences. 2014;14(6):6-12.

2. Massoud R, Hadiani MR, Hamzehlou P, Khosravi-Darani K. Bioremediation of heavy metals in food industry: Application of Saccharomyces cerevisiae. Electronic Journal of Biotechnology. 2019; 37:56-60.

doi.org/10.1016/j.ejbt.2018.11.003

3. Sardar K, Ali S, Hameed S, Afzal S, Fatima S, Shakoor MB, et al. Heavy metals contamination and what are the impacts on living organisms. Greener Journal of Environmental management and public safety. $2013 ; 2(4): 172-9$.

\subsection{0/GJEMPS.2013.4.060413652}

4. Gheshlagh FS-N, Ziarati P, Bidgoli SA. Seasonal fluctuation of heavy metal and nitrate pollution in ground water of farmlands in Talesh, Gilan, Iran. International Journal of Farming and Allied Sciences. 2013;2:836-41.

5. Ziarati P, Moslehishad M, Mohammad-Makki FM. Novel adsorption method for contaminated water by wild endemic almond: Amygdalus scoparia. Biosciences biotechnology research asia. 2016;13(1):147-53.

6. Galadima A, Muhammad N, Garba Z. Spectroscopic investigation of heavy metals in waste water from University students' halls of residence. Int J Chem. 2010;20(4):239-44.

7. Makki FM, Ziarati P. Determination of histamine and heavy metal concentrations in tomato pastes and fresh tomato (Solanum lycopersicum) in Iran. Biosci Biotechnol Res Asia. 2014;11(2):537-44.

doi: http://dx.doi.org/10.13005/bbra/1304

8. Odokuma L, Akponah E. Effect of nutrient supplementation on biodegradation and metal uptake by three bacteria in crude oil impacted fresh and brackish waters of the Niger Delta. Journal of Cell and Animal Biology. 2012;4(1):001-18.

9. Sarma B, Acharya C, Joshi S. Pseudomonads: a versatile bacterial group exhibiting dual resistance to metals and antibiotics. Afr J Microbiol Res. 2010;4(25):2828-35.

10. Mishra V. Biosorption of zinc ion: a deep comprehension. Applied Water Science. 2014;4(4):311-32.

DOI: $10.1007 / \mathrm{s} 13201-013-0150-\mathrm{x}$

11. Wang J, Chen C. Biosorbents for heavy metals removal and their future. Biotechnology advances. 2009;27(2):195-226.

doi.org/10.1016/j.biotechadv.2008.11.002

12. Lee T, Park J-w, Lee J-H. Waste green sands as reactive media for the removal of zinc from water. Chemosphere. 2004;56(6):571-81. 
DOI: $10.1016 /$ j.chemosphere.2004.04.037

13. Abdelwahab O, Amin N, El-Ashtoukhy EZ. Removal of zinc ions from aqueous solution using a cation exchange resin. Chemical Engineering Research and Design. 2013;91(1):165-73.

/doi.org/10.1016/j.cherd.2012.07.005

14. Arshad M, Zafar MN, Younis S, Nadeem R. The use of Neem biomass for the biosorption of zinc from aqueous solutions. Journal of Hazardous Materials. 2008;157(2-3):534-40.

doi.org/10.1016/j.jhazmat.2008.01.017

15. Baig KS, Doan H, Wu J. Multicomponent isotherms for biosorption of Ni2+ and $\mathrm{Zn} 2+$. Desalination. 2009;249(1):429-39.

DOI: $10.1016 /$ j.desal.2009.06.052

16. MacDiarmid CW, Milanick MA, Eide DJ. Biochemical Properties of Vacuolar Zinc Transport Systems ofSaccharomyces cerevisiae. Journal of Biological Chemistry. 2002;277(42):39187-94.

DOI: $10.1074 /$ jbc.M205052200

17. Rebar E, Miller J. Design and applications of engineered zinc finger proteins. Biotech International. 2004:20-3.

DOI: $10.1016 /$ j.gene.2005.09.011

18. Azad SK, Shariatmadari F, Torshizi MK. Production of zinc-enriched biomass of Saccharomyces cerevisiae. Journal of Elementology. 2014;19(2).

DOI:10.5601/jelem.2014.19.2.655

19. Gerwien F, Skrahina V, Kasper L, Hube B, Brunke S. Metals in fungal virulence. FEMS microbiology reviews. 2018;42(1):fux050.

doi.org/10.1093/femsre/fux050

20. Andreini C, Banci L, Bertini I, Rosato A. Zinc through the three domains of life. Journal of proteome research. 2006;5(11):3173-8.

doi: $10.1021 / \operatorname{pr} 0603699$.

21. North M, Steffen J, Loguinov AV, Zimmerman GR, Vulpe CD, Eide DJ. Genome-wide functional profiling identifies genes and processes important for zinc-limited growth of Saccharomyces cerevisiae. PLoS genetics. $2012 ; 8(6)$.

DOI: 10.1371/journal.pgen.1002699

22. MacDiarmid CW, Gaither LA, Eide D. Zinc transporters that regulate vacuolar zinc storage in Saccharomyces cerevisiae. The EMBO journal. 2000;19(12):2845-55.

doi: 10.1093/emboj/19.12.2845

23. Li L, Kaplan J. The yeast gene MSC2, a member of the cation diffusion facilitator family, affects the cellular distribution of zinc. Journal of Biological Chemistry. 2001;276(7):5036-43.

DOI: $10.1074 /$ jbc.M008969200

24. Ellis CD, MacDiarmid CW, Eide DJ. Heteromeric protein complexes mediate zinc transport into the secretory pathway of eukaryotic cells. Journal of Biological Chemistry. 2005;280(31):28811-8.

DOI: 10.1074/jbc.M505500200 
25. Cain A, Vannela R, Woo LK. Cyanobacteria as a biosorbent for mercuric ion. Bioresource technology. 2008;99(14):6578-86.

https://doi.org/10.1016/j.biortech.2007.11.034

26. Jasrotia S, Kansal A, Mehra A. Performance of aquatic plant species for phytoremediation of arseniccontaminated water. Appl Water Sci 7 (2): 889-896. 2017.

DOI: $10.1007 / \mathrm{s} 13201-015-0300-4$

27. Halder S. Bioremediation of heavy metals through fresh water microalgae: a review. Scholars Academic Journal of Biosciences. 2014;2(11):825-30.

28. Machado MD, Soares EV, Soares HM. Removal of heavy metals using a brewer's yeast strain of Saccharomyces cerevisiae: chemical speciation as a tool in the prediction and improving of treatment efficiency of real electroplating effluents. Journal of hazardous materials. 2010;180(1-3):347-53.

DOI: $10.1016 /$ j.jhazmat.2010.04.037

29. Lapeña D, Kosa G, Hansen LD, Mydland LT, Passoth V, Horn SJ, et al. Production and characterization of yeasts grown on media composed of spruce-derived sugars and protein hydrolysates from chicken byproducts. Microbial cell factories. 2020;19(1):19.

DOI: $10.1186 / \mathrm{s} 12934-020-1287-6$

30. Ritala A, Häkkinen ST, Toivari M, Wiebe MG. Single cell protein - state-of-the-art, industrial landscape and patents 2001-2016. Frontiers in microbiology. 2017;8:2009.

doi: 10.3389/fmicb.2017.02009

31. Øverland M, Skrede A. Yeast derived from lignocellulosic biomass as a sustainable feed resource for use in aquaculture. Journal of the Science of Food and Agriculture. 2017;97(3):733-42.

DOI: $10.1002 /$ jsfa. 8007

32. Kurcz A, Błażejak S, Kot AM, Bzducha-Wróbel A, Kieliszek M. Application of industrial wastes for the production of microbial single-cell protein by fodder yeast Candida utilis. Waste and Biomass Valorization. 2018;9(1):57-64.

DOI: $10.1007 / \mathrm{s} 12649-016-9782-\mathrm{Z}$

33. Øverland M, Karlsson A, Mydland LT, Romarheim OH, Skrede A. Evaluation of Candida utilis, Kluyveromyces marxianus and Saccharomyces cerevisiae yeasts as protein sources in diets for Atlantic salmon (Salmo salar). Aquaculture. 2013;402:1-7.

DOI: $10.1016 /$ j.aquaculture.2013.03.016

34. Wang J, Chen C. Biosorption of heavy metals by Saccharomyces cerevisiae: a review. Biotechnology advances. 2006;24(5):427-51.

doi: $10.1016 /$ j.biotechadv.2006.03.001.

35. Chen C, Wang J-L. Characteristics of Zn2+ biosorption by Saccharomyces cerevisiae. Biomedical and environmental sciences: BES. 2007;20(6):478-82.

36. Waldron KJ, Rutherford JC, Ford D, Robinson NJ. Metalloproteins and metal sensing. Nature. 2009;460(7257):823-30.

DOI: $10.1038 /$ nature08300 
37. Amich J, Vicentefranqueira R, Leal F, Calera JA. Aspergillus fumigatus survival in alkaline and extreme zinc-limiting environments relies on the induction of a zinc homeostasis system encoded by the zrfC and aspf2 genes. Eukaryotic cell. 2010;9(3):424-37.

DOI: 10.1128/EC.00348-09

38. Tahir A, Lateef Z, Abdel-Megeed A, Sholkamy EN, Mostafa AA. In vitro compatibility of fungi for the biosorption of zinc (II) and copper (II) from electroplating effluent. Current Science (00113891). 2017;112(4).

DOI: $10.18520 / \mathrm{cs} / \mathrm{v} 112 / \mathrm{i} 04 / 839-844$

39. Aksu Z. Equilibrium and kinetic modelling of cadmium (II) biosorption by C. vulgaris in a batch system: effect of temperature. Separation and Purification Technology. 2001;21(3):285-94.

doi.org/10.1016/S1383-5866(00)00212-4

40. Xiao X, Luo S, Zeng G, Wei W, Wan Y, Chen L, et al. Biosorption of cadmium by endophytic fungus (EF) Microsphaeropsis sp. LSE10 isolated from cadmium hyperaccumulator Solanum nigrum L. Bioresource technology. 2010;101(6):1668-74.

doi: 10.1016/j.biortech.2009.09.083

41. Bajpai P. Single cell protein production from lignocellulosic biomass: Springer; 2017.

Figure legend:

Figure1. A) PCR products on 1.5\% agarose gel. The samples which expressed Zrt1 and Fet4 genes illustrated fragment patterns of $2102 \mathrm{bp}$ and $165 \mathrm{bp}$. M: marker, (+): positive control, (-): negative control, 41-44: number of samples. B) PCR ITS products on 1.5\% agarose gel. The samples which illustrated ITS fragment patterns identified as yeast strains. M: marker, 1-3: yeast strains. C)Phylogenetic tree of sequenced samples. Samples 2and3 were identified as $S$. cerevisiae yeasts.

Figure 2. The effect of supplementing the SDB culture medium with $\mathrm{ZnSO}_{4}$ on growth rate of $S$. cerevisiae . The maximum growth rate observed in $25 \mu \mathrm{g} / \mathrm{ml}$ of zinc concentration at 24 hours after inoculation

Figure 3. Differentially expression levels of Zrt1 and Fet4 inS. cerevisiae under supplementing the SDB medium with different concentrations of zinc and after $24 \mathrm{~h}$ of incubation, versus control (without the addition of zinc). The maximum Zrt1 transcript level was observed in $25 \mu \mathrm{g} / \mathrm{ml}$ of zinc concentration. While Fet4 transcript level found to be significantly increased in the presence of $50 \mu \mathrm{g} / \mathrm{ml}$ of zinc. The p values were indicated as ${ }^{*} \mathrm{p}<0.05,{ }^{* *} \mathrm{p}<0.01$, and ${ }^{* * *} \mathrm{p}<0.001$

Figure 4. Differentially expression levels of Zrt1 and Fet4 inS. cerevisiae in $\mathrm{pH} 3,4,5$ and 6 versus control (pH 5.8). The maximum Fet4 transcript level was observed in $\mathrm{pH} 4$, while the equal increment of $\mathrm{Zrt1}$ and Fet4 expression was observed in $\mathrm{pH} 6{ }^{*}$ Represents $\mathrm{p}$ value $<0.05$. 

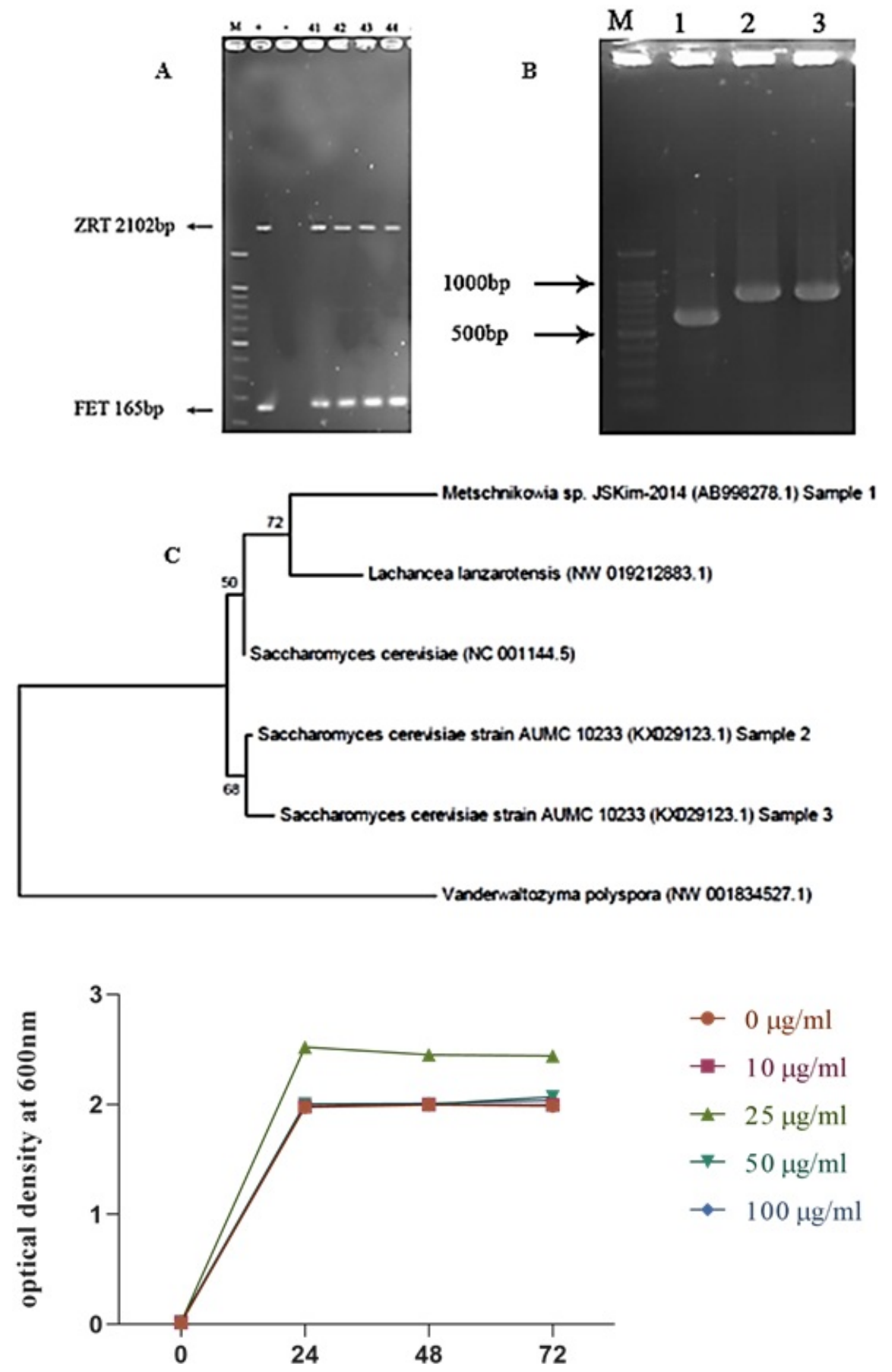

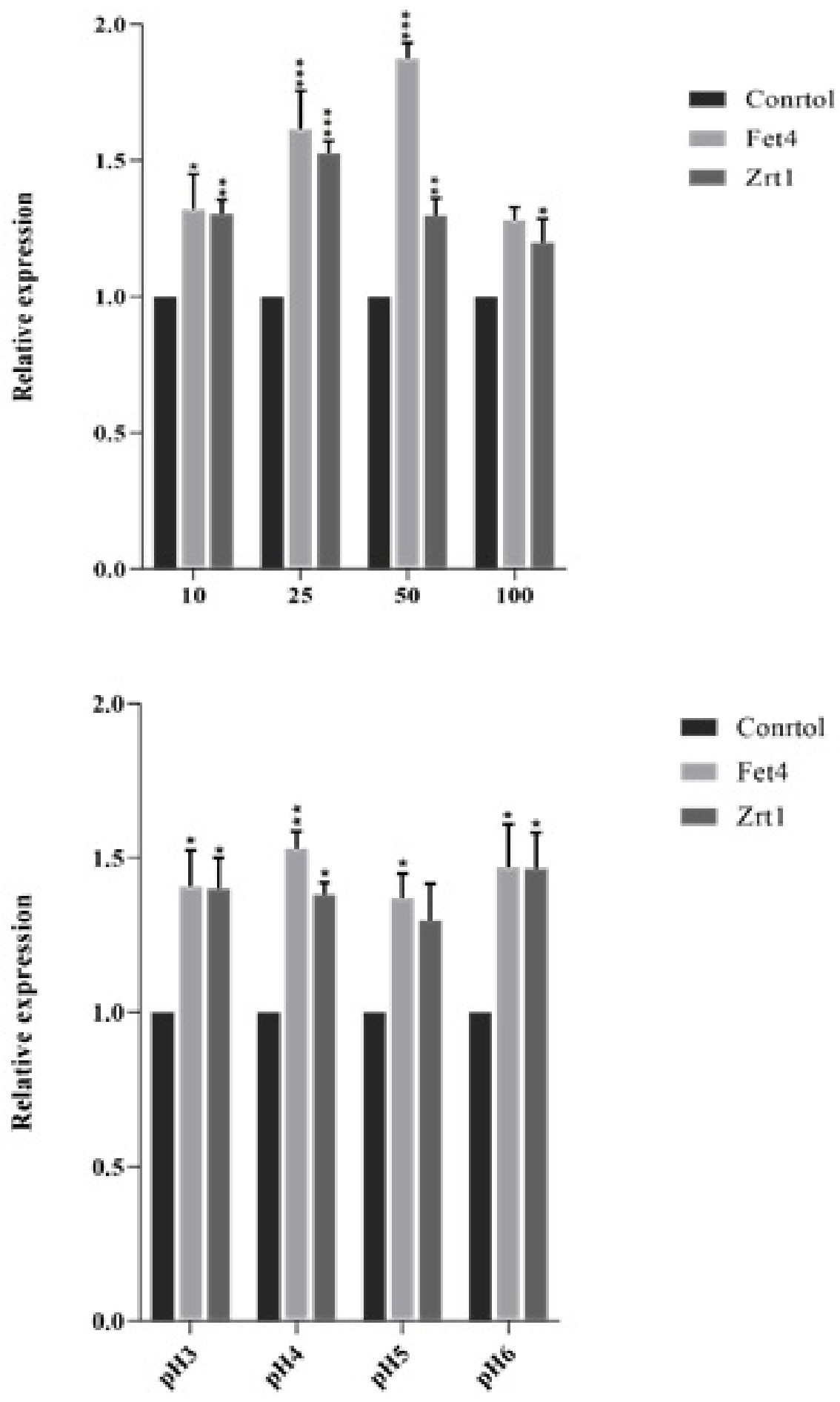